\section{Therapeutic management of acute respiratory infections in AIEPI}

Manejo terapeutico de infecciones respiratorias agudas en AIEPI

Nancy Isabel Abad-Martínez

Degree in Nursing, Faculty of Nursing, Universidad

Católica de Cuenca, Azogues Campus.

niabadm@ucacue.edu.ec,https://orcid.org/0000-

0002-5888-5521

Andrés Alexis Ramírez-Coronel

Doctor of Neuropsychology. Faculty of Nursing at the

Catholic University of Cuenca, Azogues Campus,

Psychometrics Laboratory of the Center for Research

Innovation and Technology Transfer, Maestría en

Gestión del Cuidado - Postgraduate Studies at the

Catholic University of Cuenca.

andres.ramirez@ucacue.edu.ec, https://orcid.org

/0000-0002-6996-0443

Pedro Carlos Martínez-Suárez

$\mathrm{PhD}$ in Psychology. Faculty of Clinical Psychology,

Universidad Católica de Cuenca, Psychometrics

Laboratory of the Center for Research, Innovation

and Technology Transfer, Maestría en Psicología

Clínica con Mención en Psicoterapia - Postgraduate

Studies at the Catholic University of Cuenca.

pmartinezs@ucacue.edu.ec,0000-0002-1441-3821

Fanny Mercedes González-León

Degree in Nursing, Faculty of Nursing, Universidad

Católica de Cuenca, Azogues Campus. Maestría en

Psicología Clínica con Mención en Psicoterapia -

Postgraduate Studies at the Catholic University of

Cuenca. fmgonzalezl@ucacue.edu.ec 0000-0002-

5316-5701

Lilian Azucena Romero-Sacoto

Degree in Nursing, Faculty of Nursing, Universidad

Católica de Cuenca, Azogues Campus. Maestría en

Psicología Clínica con Mención en Psicoterapia -

Postgraduate Studies at the Catholic University of

Cuenca.1romeros@ucacue.edu.ec,0000-0002-0445-

4179

Guayaquil - Ecuador

http://www.jah-journal.com/index.php/jah

Journal of American health

Enero - Marzo vol. 4. Num. 1- 2021

Esta obra está bajo una Licencia Creative Commons

Atribución-NoComercial-Compartirlgual 4.0 Internacional.

RECIBIDO: 9 DE FEBRERO 2020

ACEPTADO: 3 DE DICIEMBRE 2020

PUBLICADO: 4 DE ENERO 2021
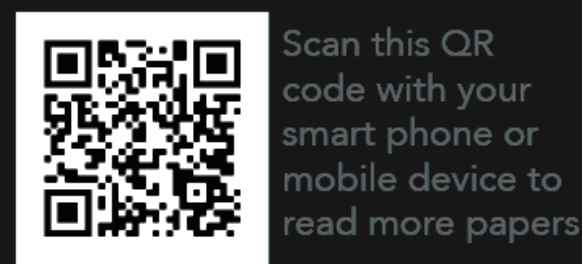

\section{ABSTRACT}

To determine the therapeutic management of acute respiratory infections within the $\mathrm{IMCl}$ strategy in children from 2 to 59 months in the health centres of Déleg, Javier Loyola and San Miguel de Porotos. Materials and Methods: Descriptive study, cross-sectional, quantitative, sample of 314 children attended in the health center Déleg, Javier Loyola and San Miguel de Porotos, diagnosed with acute respiratory infection. Instrument: A collection form was designed with the respective validation by experts. Data were collected from the medical history of children from 2 to 59 months. Results: Male predominance $56.7 \%$, age 2 to 11 months $28.6 \%$, predominance of cough or common cold $31.4 \%$ followed by pharyngo-tonsillitis $22.2 \%$, therapeutic management of pharyngo-tonsillitis is based on the use of amoxicillin and paracetamol 54.5\%, in cough or cold receive paracetamol $30.8 \%$ and other children with the same diagnosis receive paracetamol plus loratadine $72 \%$. In simple counseling, sore throat relief predominates $80.0 \%$ and cough relief $65 \%$. Conclusion: The classification specified in the IMCl strategy is not met. There is a high percentage of diagnoses of pharyngotonsillitis that are not specified as being viral or bacterial, and other cases are treated with amoxicillin plus clavulanic acid.

KEYWORDS: Acute respiratory infections, therapeutic management, IMCl, children.

\section{RESUMEN}

Determinar el manejo terapéutico de las infecciones respiratorias agudas dentro de 
la estrategia AIEPI en niños de 2 a 59 meses en los centros de salud de Déleg, Javier Loyola y San Miguel de Porotos. Materiales y Métodos: Estudio descriptivo, corte transversal, cuantitativo, muestra de 314 niños atendidos en el centro de salud Déleg, Javier Loyola y San Miguel de Porotos, diagnosticados de infección respiratoria aguda. Instrumento: Se diseñó un formulario de recolección con la respectiva validación por expertos. Los datos se recolectaron de la historia clínica de los niños de 2 a 59 meses. Resultados: Predominio del sexo masculino $56,7 \%$, edad de 2 a 11 meses $28.6 \%$, predomina la tos o resfriado común $31,4 \%$ seguido de faringoamigdalitis $22,2 \%$, el manejo terapéutico de faringoamigdalitis se basa en el uso amoxicilina y paracetamol 54,5\%, en tos o resfriado reciben paracetamol
$30.8 \%$ y otros niños con el mismo diagnóstico reciben paracetamol más loratadina $72 \%$. En consejería simple predomina el alivio del dolor de garganta $80.0 \%$ y alivio de la tos $65 \%$. Conclusión: No se cumple con la clasificación especificada en la estrategia AIEPI, existiendo un alto porcentaje de diagnósticos de faringoamigdalitis que no se especifica si es viral o bacteriana y reciben tratamiento con amoxicilina otros casos con amoxicilina más ácido clavulámico, existe niños que reciben tratamiento con loratadina e ibuprofeno que no consta en decidir y tratar.

PALABRAS CLAVE: Infecciones respiratorias agudas, manejo terapéutico, AIEPI, niños.

\section{INTRODUCTION}

The Integrated Management of Childhood IIIness (IMCI) strategy emerged in 1992 as a proposal by the World Health Organization (WHO) and the United Nations Children's Fund (UNICEF) to reduce high rates of child mortality and the incidence of infectious disease episodes by working to modify individual or human group risk factors and responding to specific disease problems. The strategy integrated programs of proven effectiveness such as the management of acute diarrheal disease, acute respiratory infection, among others, with health protection initiatives such as the growth and development program and the expanded immunization plans (1). In addition, the strategy defines three components: first, the strengthening of the organization, of the services that it aims to rationalize, health services, and guarantee the timeliness of these services, taking advantage of all contact with children and their families and undertaking health promotion and disease prevention actions; second, the improvement of family and community practices in care and protection, the purpose of which is to develop the social competencies required for decision-making that favours the care and protection of children; and third, the improvement of the skills of health personnel, which seeks to develop human talent and skills that contribute to improving the care, protection and protection of children (2).

In Latin America, the IMCl strategy has gone beyond prevention with a risk focus, which is the responsibility of health services, and has taken up a public health approach that takes into account the social determinants that condition individual and collective well-being, to unleash a comprehensive approach that guarantees the right of children to health and the full development of their potential, as a result of an effort by the family and society as a whole, where local planning, public policies, transdisciplinarity, trans-sectoral program coordination and social participation play a fundamental role(2). 
A small group of diseases are responsible for a large part of child mortality in developing countries, including pneumonia, measles, malaria, diarrhea and malnutrition. These diseases often co-exist, so a top-down approach to child health focusing on a single disease is not appropriate. This $\mathrm{IMCl}$ strategy offers a systematic approach to assessing the overall situation of the child by classifying symptoms, categorizing the disease and identifying appropriate treatment (2). In addition, it provides a systematic approach to assessing the child's overall situation by categorizing symptoms, categorizing the condition, and identifying appropriate treatment (3).

$\mathrm{IMCl}$ contains effective treatment of acute respiratory infections, for correct management at home through simple practices to recover and maintain health status, allowing caregivers to identify general danger and alarm signs to go immediately to the health unit to avoid complications and even death.

Acute respiratory infections (ARIs) are very common and represent a major public health problem worldwide. They are a group of diseases that occur in the respiratory system, caused by different microorganisms such as viruses and bacteria, which begin suddenly and last less than two weeks. But depending on a person's general condition, they can become complicated and life-threatening, as in the case of pneumonia1. The most affected population is children under five years of age and in this age group, the cause of infection in $95 \%$ of cases is the virus, which has a good prognosis, but $5 \%$ may suffer complications such as otitis, sinusitis and pneumonia. The main symptoms of ARI are: fever, general malaise, congestion and nasal discharge. In addition, symptoms such as cough, sore throat, expectoration and breathing difficulty may occur. Globally, ARIs represent a high economic and disease burden on health systems, accounting for the deaths of four million children worldwide each year (4).

Acute respiratory infections (ARIs) are self-limiting; errors in diagnosis and treatment are a well-known problem. There is evidence of overuse of antimicrobials ( $90 \%$ of cases) and symptomatic medications ( $98 \%$ of cases), and pneumonia, the main complication of ARIs, is undiagnosed and untreated.

The effectiveness, impact and costs of the $\mathrm{IMCl}$ strategy were evaluated in a multi-country study (Multi Country Evaluation), which demonstrated direct benefits on child health in several countries. Some studies report a slight increase in short-term costs, while others find no significant difference in treatment costs. Despite improved treatment, there is evidence that the IMCl strategy can promote rational use of antibiotics, leading to direct health benefits and cost savings (3).

The objective of this study was to determine the therapeutic management of acute respiratory infections within the IMCl strategy in the health centres of Déleg, Javier Loyola and San Miguel de Porotos.

\section{MATERIALS AND METHODS}

A descriptive study of cross-sectional, quantitative, the universe consists of all children who were served in the health center of Déleg, Javier Loyola and San Miguel de Porotos in the year 2018 a total of 314 children who were diagnosed with acute respiratory infection, we applied the formula for finite population testing to determine the sample, simple random sampling for the health center of Déleg with 175, 82 children served in the Health Center of Javier Loyola and 57 of San Miguel de Porotos. 
A form was designed for the collection of information based on the proposed objectives, and the validation was carried out by family medicine specialists who work in operational primary health care units. Data were collected from the clinical history of children from 2 to 59 months. A descriptive analysis of the variables was performed, the results were expressed in frequencies and percentages and presented in tables.

\section{RESULTS}

The children most vulnerable to presenting acute respiratory infections in the health centres of Deleg, Javier Loyola and San Miguel de Porotos, were at the age of 02 to 11 months, with $28.6 \%$, followed by the age of 24 to 35 with $20.7 \%$ and $20.3 \%$ were children corresponding to the age of 12 to 23 months.

Table 1. Age-Health Center

\begin{tabular}{|c|c|c|c|c|c|c|c|c|c|c|}
\hline & & \multirow{2}{*}{\multicolumn{2}{|c|}{ Déleg }} & \multirow{2}{*}{\multicolumn{2}{|c|}{ Javier Loyola }} & \multirow{2}{*}{\multicolumn{2}{|c|}{$\begin{array}{l}\text { San Miguel } \\
\text { Porotos }\end{array}$}} & \multirow{3}{*}{ de } & \multirow{2}{*}{\multicolumn{2}{|c|}{ Total }} \\
\hline & & & & & & & & & & \\
\hline \multirow{6}{*}{ Age } & & $N$ & $\%$ & $N$ & $\%$ & $N$ & $\%$ & & $N$ & $\%$ \\
\hline & $\begin{array}{l}02-11 \\
\text { months. }\end{array}$ & 40 & 22.8 & 18 & 21.9 & 32 & 56.1 & & 90 & 28.6 \\
\hline & $\begin{array}{l}12-23 \\
\text { months }\end{array}$ & 28 & 16 & 22 & 26.8 & 14 & 24.5 & & 64 & 20.3 \\
\hline & $\begin{array}{l}24-35 \\
\text { months }\end{array}$ & 47 & 26.8 & 13 & 15.8 & 5 & 8.7 & & 65 & 20.7 \\
\hline & $\begin{array}{l}36-47 \\
\text { months. }\end{array}$ & 25 & 14.2 & 11 & 13.4 & 5 & 8.7 & & 41 & 13.0 \\
\hline & $\begin{array}{l}48-59 \\
\text { months }\end{array}$ & 35 & 20 & 18 & 21.9 & 1 & 1.7 & & 54 & 17.1 \\
\hline \multicolumn{2}{|l|}{ Total } & \multicolumn{2}{|c|}{$5 \quad 55.7$} & \multicolumn{2}{|c|}{99.8} & \multicolumn{2}{|c|}{99.7} & 314 & 99.8 & \\
\hline
\end{tabular}

Tabla 2. Sexo.

\begin{tabular}{lcc} 
& $\boldsymbol{f}$ & $\boldsymbol{\%}$ \\
\hline Female & 139 & 44,3 \\
Male & 175 & 56,7 \\
Total & 314 & 100 \\
\hline
\end{tabular}

In relation to the sex of the children who present acute respiratory infections there is a predominance of the male sex with $56.7 \%$ in relation to the female sex of $44.3 \%$. 
Table 3. Treatment-Diagnosis of Acute Respiratory Infections.

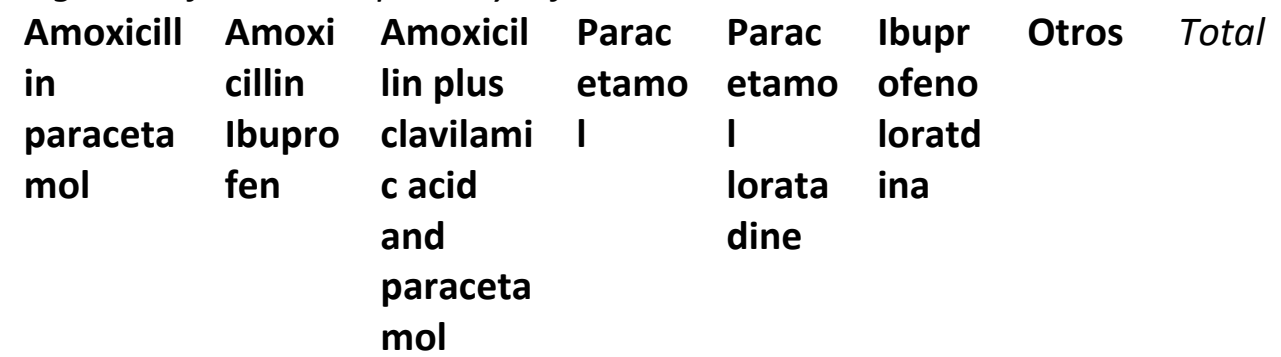

\begin{tabular}{|c|c|c|c|c|c|c|c|c|c|c|c|}
\hline \multirow{10}{*}{$\begin{array}{r}\text { Diagnosi } \\
\text { s of } \\
\text { Respirat } \\
\text { ory } \\
\text { Infection } \\
\mathrm{s} \\
\text { Acute. }\end{array}$} & & $\mathbf{N}$ & $\%$ & N \% & $\mathbf{N}$ & $\%$ & $\begin{array}{l}N \\
\%\end{array}$ & $\begin{array}{l}N \\
\%\end{array}$ & $\underset{\%}{N}$ & $\begin{array}{l}N \\
\%\end{array}$ & $\%^{N}$ \\
\hline & $\begin{array}{l}\text { Bronc } \\
\text { hiolitis }\end{array}$ & 6 & 5.4 & $\begin{array}{l}0 \\
0.0\end{array}$ & 3 & 23 & $\begin{array}{l}4 \\
3.7\end{array}$ & $\begin{array}{l}0 \\
1.0\end{array}$ & $\begin{array}{l}0 \\
0.0\end{array}$ & $\begin{array}{l}1 \\
12.5\end{array}$ & $\begin{array}{l}14 \\
4.4\end{array}$ \\
\hline & & $\begin{array}{l}2 \\
1.8\end{array}$ & & $\begin{array}{l}0 \\
0.0\end{array}$ & 0 & 00 & $\begin{array}{l}1 \\
0.9\end{array}$ & $\begin{array}{l}0 \\
0.0\end{array}$ & $\begin{array}{l}0 \\
0.0\end{array}$ & $\begin{array}{l}0 \\
0.0\end{array}$ & $\begin{array}{l}3 \\
0.8\end{array}$ \\
\hline & & $\begin{array}{l}0 \\
0.0\end{array}$ & & $\begin{array}{l}0 \\
0.0\end{array}$ & $\begin{array}{l}2 \\
15.3 \\
\end{array}$ & & $\begin{array}{l}26 \\
24.2 \\
\end{array}$ & $\begin{array}{l}1 \\
2.3 \\
\end{array}$ & $\begin{array}{l}0 \\
0.0\end{array}$ & $\begin{array}{l}0 \\
0.0\end{array}$ & $\begin{array}{l}29 \\
9.2\end{array}$ \\
\hline & $\begin{array}{l}\text { Whee } \\
\text { zing }\end{array}$ & $\begin{array}{l}0 \\
0\end{array}$ & 0. & $\begin{array}{l}0 \\
0.0\end{array}$ & 1 & 7.6 & $\begin{array}{l}3 \\
2.8\end{array}$ & $\begin{array}{l}0 \\
0.0\end{array}$ & $\begin{array}{l}0 \\
0.0\end{array}$ & $\begin{array}{l}0 \\
0.0\end{array}$ & $\begin{array}{l}4 \\
1.2\end{array}$ \\
\hline & $\begin{array}{l}\text { Recurr } \\
\text { ent } \\
\text { wheez } \\
\text { ing. }\end{array}$ & $\begin{array}{l}0 \\
0.0\end{array}$ & & $\begin{array}{l}0 \\
0.0\end{array}$ & 0 & 0.0 & $\begin{array}{l}1 \\
0.9\end{array}$ & $\begin{array}{l}0 \\
0.0\end{array}$ & $\begin{array}{l}0 \\
0.0\end{array}$ & $\begin{array}{l}0 \\
0.0\end{array}$ & $\begin{array}{l}1 \\
0.3\end{array}$ \\
\hline & & $\begin{array}{l}9 \\
8.1\end{array}$ & & $\begin{array}{l}0 \\
0.0\end{array}$ & $\begin{array}{l}2 \\
15.3\end{array}$ & & $\begin{array}{l}11 \\
10.2\end{array}$ & $\begin{array}{l}1 \\
2.3\end{array}$ & $\begin{array}{l}0 \\
0.0\end{array}$ & $\begin{array}{l}0 \\
0.0\end{array}$ & $23 \quad 7.3$ \\
\hline & Croup & 10 & 9 & $\begin{array}{l}0 \\
0.0\end{array}$ & $\begin{array}{l}0 \\
0.0\end{array}$ & & $\begin{array}{l}33 \\
30.8\end{array}$ & $\begin{array}{l}31 \\
72.0\end{array}$ & $\begin{array}{l}30 \\
100\end{array}$ & $\begin{array}{l}3 \\
37.5\end{array}$ & $\begin{array}{l}107 \\
34\end{array}$ \\
\hline & & $\begin{array}{l}60 \\
54.4\end{array}$ & & $\begin{array}{l}3 \\
100\end{array}$ & $\begin{array}{l}2 \\
15.3\end{array}$ & & $\begin{array}{l}1 \\
0.9\end{array}$ & $\begin{array}{l}4 \\
9.3\end{array}$ & $\begin{array}{l}0 \\
0.0\end{array}$ & $\begin{array}{l}0 \\
0.0\end{array}$ & $\begin{array}{l}70 \\
22.2\end{array}$ \\
\hline & Otros & $\begin{array}{l}23 \\
20.9\end{array}$ & & $\begin{array}{l}0 \\
00\end{array}$ & $\begin{array}{l}3 \\
23 .\end{array}$ & & $\begin{array}{l}27 \\
25.2\end{array}$ & $\begin{array}{l}6 \\
13,9\end{array}$ & $\begin{array}{l}0 \\
0.0\end{array}$ & $\begin{array}{l}4 \\
50.0\end{array}$ & $\begin{array}{l}63 \\
20.0\end{array}$ \\
\hline Total & & $\begin{array}{l}110 \\
99.6\end{array}$ & & $\begin{array}{l}3 \\
100\end{array}$ & $\begin{array}{l}13 \\
99.5\end{array}$ & & $\begin{array}{l}107 \\
99.6\end{array}$ & $\begin{array}{l}43 \\
99.8\end{array}$ & $\begin{array}{l}30 \\
100\end{array}$ & $\begin{array}{l}8 \\
100\end{array}$ & $\begin{array}{l}314 \\
99.4\end{array}$ \\
\hline
\end{tabular}

Within the applied treatment there is evidence of indiscriminate use of antibiotics such as amoxicillin in pharyngoamigadalitis $54.4 \%$ without specifying as it is evidenced in the classification or diagnosis of the $\mathrm{IMCl}$ strategy if it is bacterial or viral, in cough or common cold with $9 \%$, The use of paracetamol is also observed, which is indicated in deciding and treating with $30.8 \%$ in common cough or cold and recurrent wheezing with 24.2 , it is important to 
mention that a therapeutic with ibuprofen and loratadine is applied, which are not included in the integrated care of prevalent diseases of childhood.

Table 4. Age-Diagnosis of Acute Respiratory Infections.

\begin{tabular}{|c|c|c|c|c|c|c|c|c|}
\hline $\begin{array}{l}\text { Bronqu } \\
\text { iolitis }\end{array}$ & $\begin{array}{l}\text { Sibila } \\
\text { ncias }\end{array}$ & $\begin{array}{l}\text { Sibila } \\
\text { ncias } \\
\text { recurr } \\
\text { entes }\end{array}$ & Crup & $\begin{array}{l}\text { Crup } \\
\text { leve. }\end{array}$ & $\begin{array}{l}\text { Neum } \\
\text { onía. }\end{array}$ & $\begin{array}{l}\text { Tos o } \\
\text { resfri } \\
\text { ado. }\end{array}$ & $\begin{array}{l}\text { Farin } \\
\text { goam } \\
\text { igdali } \\
\text { tis }\end{array}$ & $\begin{array}{l}\text { Otros } \\
\text {. }\end{array}$ \\
\hline
\end{tabular}

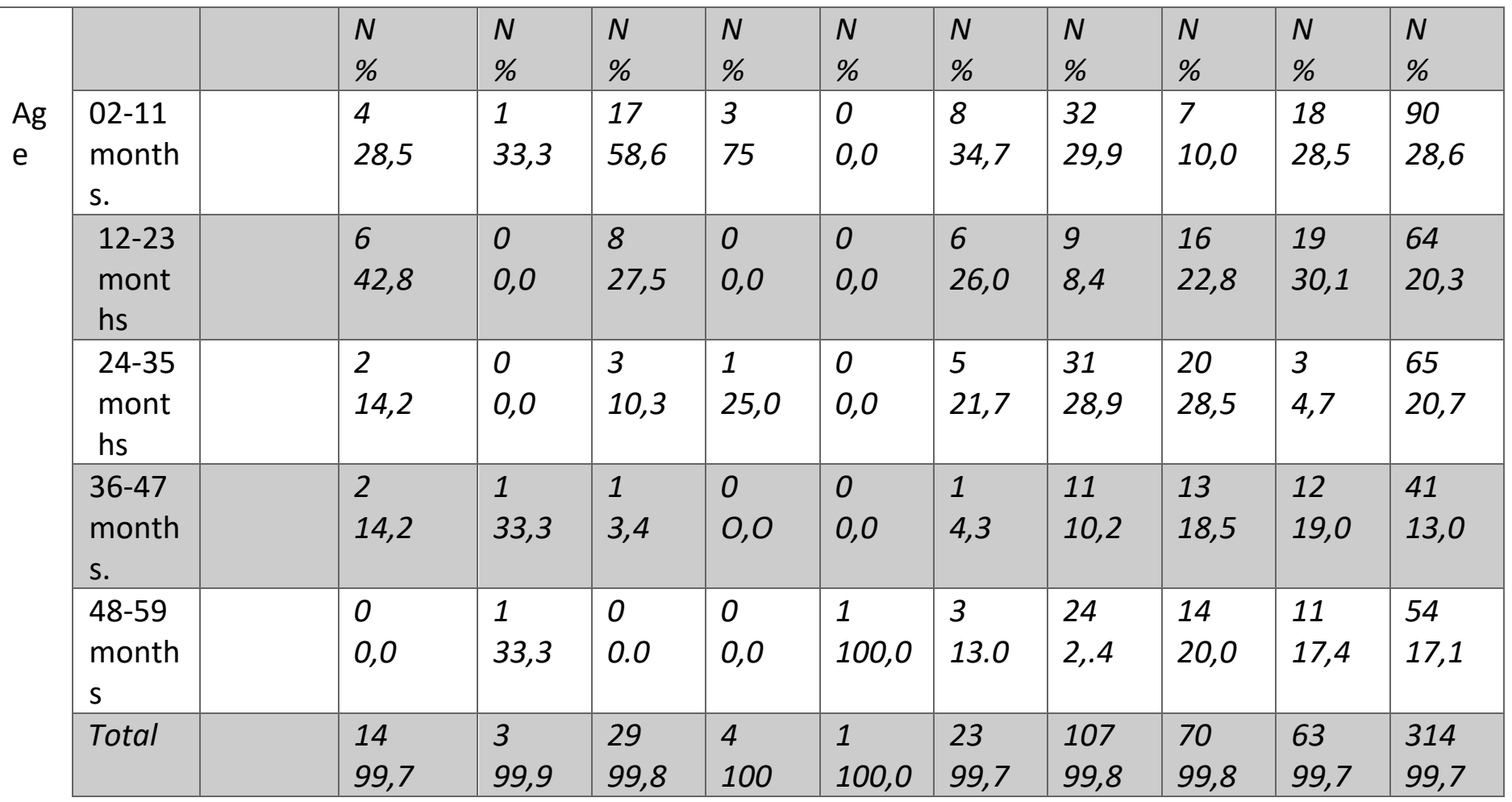

The age of the child is directly related to the presentation of the acute respiratory infections, the age that prevails is of 02 to 11 months where the greater percentage corresponds to the cough or cold with $29.9 \%$ of children, equal classification is in the age of 24 to 35 months with $28.9 \%$ and faringoamigdaitis with $28.5 \%$ in this same age. 
Table 5. Diagnosis of respiratory infections - Health Centers.

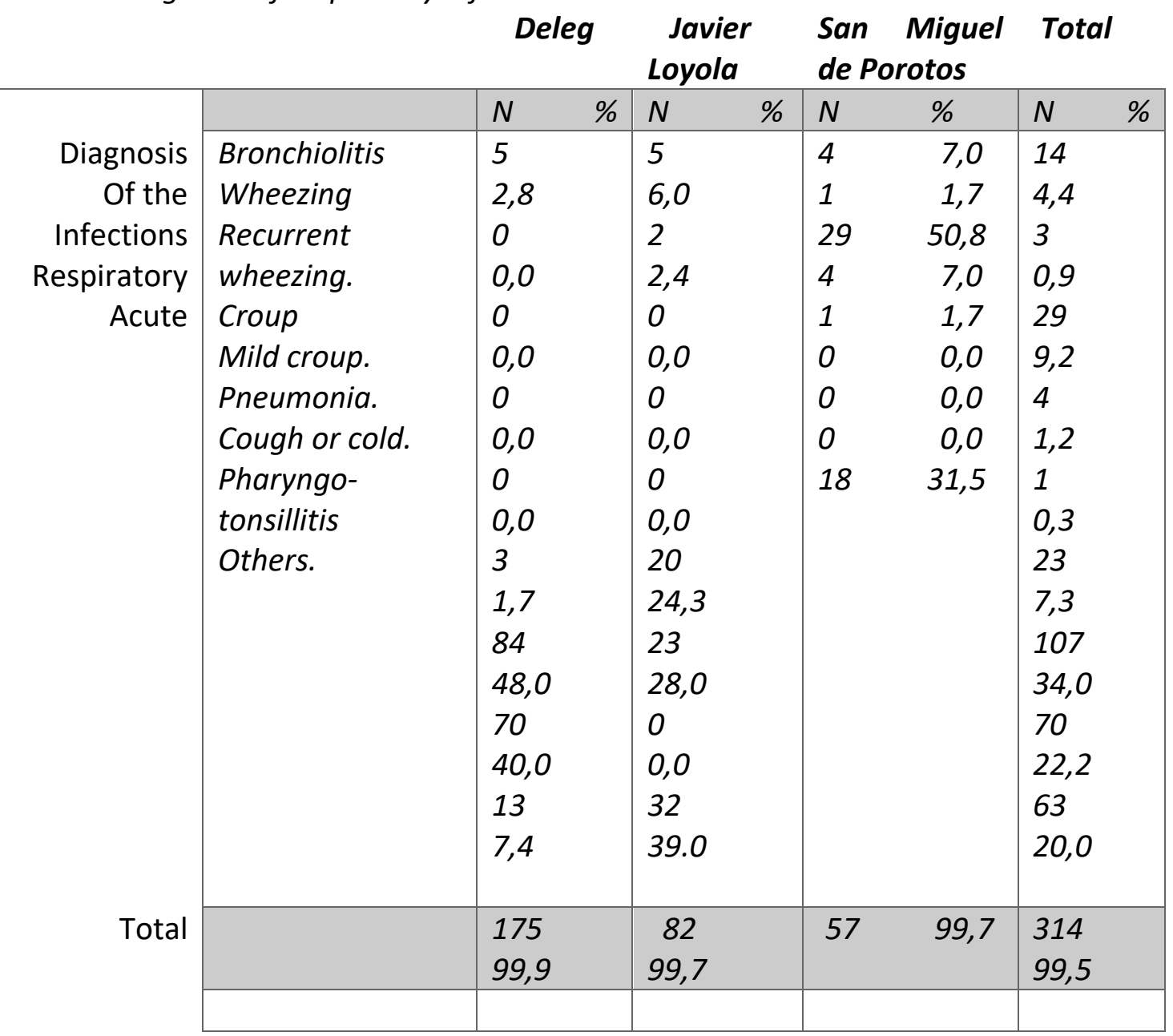

It is evident that the presentation of acute respiratory infection is different in the different health units, as can be seen in the Deleg Health Centre where cough or cold prevails with 48\%, followed by pharyngo-tonsillitis with $40 \%$, the Javier Loyola Health Centre where cough or cold prevails with $28 \%$, followed by pneumonia with $24.3 \%$ while in the San Miguel de Porotos Health Centre recurrent wheezing prevails with $50.8 \%$.

Table 6. Age-Treatment.

\begin{tabular}{|c|c|c|c|c|c|c|c|}
\hline $\begin{array}{l}\text { Amoxic } \\
\text { ilina } \\
\text { Paracet } \\
\text { amol }\end{array}$ & $\begin{array}{l}\text { Amoxic } \\
\text { ilina } \\
\text { ibuprof } \\
\text { eno }\end{array}$ & $\begin{array}{l}\text { Amoxicili } \\
\text { na más } \\
\text { ácido } \\
\text { clavilámi } \\
\text { co y } \\
\text { paraceta } \\
\text { mol }\end{array}$ & $\begin{array}{l}\text { Parac } \\
\text { etam } \\
\text { ol }\end{array}$ & $\begin{array}{l}\text { Parac } \\
\text { etam } \\
\text { ol } \\
\text { Lorat } \\
\text { adina }\end{array}$ & $\begin{array}{l}\text { Ibuprofe } \\
\text { no } \\
\text { Loratdin } \\
a\end{array}$ & Otros & Total \\
\hline$N \quad \%$ & $N \quad \%$ & $N \quad \%$ & $\begin{array}{l}N \\
\%\end{array}$ & $\begin{array}{l}N \\
\%\end{array}$ & $\begin{array}{l}N \\
\%\end{array}$ & & \\
\hline $\begin{array}{l}21 \\
19\end{array}$ & $0 \quad 0,0$ & $\begin{array}{l}4 \\
30,7\end{array}$ & $\begin{array}{l}42 \\
39,2\end{array}$ & $\begin{array}{l}6 \\
13,9\end{array}$ & 1653,3 & $\begin{array}{l}1 \\
12,5\end{array}$ & $\begin{array}{l}90 \\
28,6\end{array}$ \\
\hline
\end{tabular}




\begin{tabular}{|c|c|c|c|c|c|c|c|c|}
\hline $\begin{array}{l}\text { mon } \\
\text { ths. }\end{array}$ & & & & & & & & \\
\hline $\begin{array}{l}12- \\
23 \\
\text { mo } \\
\text { nth } \\
\mathrm{s}\end{array}$ & $\begin{array}{l}24 \\
21\end{array}$ & $0 \quad 0,0$ & $\begin{array}{l}5 \\
38,4\end{array}$ & $\begin{array}{l}23 \\
21,4\end{array}$ & $\begin{array}{l}7 \\
16,2\end{array}$ & 13,3 & $\begin{array}{l}4 \\
50,0\end{array}$ & $\begin{array}{l}64 \\
20,3\end{array}$ \\
\hline $\begin{array}{l}24- \\
35 \\
\text { mo } \\
\text { nth } \\
\mathrm{s}\end{array}$ & $\begin{array}{l}21 \\
19\end{array}$ & 266,6 & $\begin{array}{l}3 \\
23,0\end{array}$ & $\begin{array}{l}18 \\
16,8\end{array}$ & $\begin{array}{l}15 \\
34,8\end{array}$ & 516,1 & $\begin{array}{l}1 \\
12,5\end{array}$ & $\begin{array}{l}65 \\
20,7\end{array}$ \\
\hline $\begin{array}{l}36- \\
47 \\
\text { mon } \\
\text { ths. }\end{array}$ & $\begin{array}{l}24 \\
21\end{array}$ & 133,3 & $\begin{array}{l}0 \\
0,0\end{array}$ & $\begin{array}{l}9 \\
8,4\end{array}$ & $\begin{array}{l}4 \\
9,3\end{array}$ & 26,6 & $\begin{array}{l}1 \\
12,5\end{array}$ & $\begin{array}{l}41 \\
13,0\end{array}$ \\
\hline $\begin{array}{l}48- \\
59 \\
\text { mon } \\
\text { ths }\end{array}$ & $\begin{array}{l}20 \\
18,8\end{array}$ & $0 \quad 0,0$ & $\begin{array}{l}1 \\
7,6\end{array}$ & $\begin{array}{l}15 \\
14,0\end{array}$ & $\begin{array}{l}11 \\
25,5\end{array}$ & 620,0 & $\begin{array}{l}1 \\
12,5\end{array}$ & $\begin{array}{l}54 \\
17,1\end{array}$ \\
\hline & $\begin{array}{l}110 \\
99,8\end{array}$ & $\begin{array}{l}3 \\
99,9\end{array}$ & $\begin{array}{l}13 \\
99,7\end{array}$ & $\begin{array}{l}107 \\
99,8\end{array}$ & $\begin{array}{l}43 \\
99,7\end{array}$ & 3099,8 & $\begin{array}{l}8 \\
100\end{array}$ & $\begin{array}{l}314 \\
99,8\end{array}$ \\
\hline
\end{tabular}

The most prescribed medication in acute respiratory infections is paracetamol in age 02-11 with $39.2 \%$, and loratadine plus paracetamol in age $24-35$ with $34.8 \%$, amoxicillin plus paracetamol with similar percentages in all ages, with higher prevalence in age 12-23 and 3447 months with $21 \%$ respectively. 
There is evidence that paracetamol is the most prescribed medicine in the three health units, in the Déleg health centre most antibiotics are prescribed such as amoxicillin plus paracetamol with $67.2 \%$, followed by the Javier Loyola health centre with $30.9 \%$ and a small percentage in the San Miguel de Porotos health centre.

Table 8. Simple Counseling - Diagnosis of Acute Respiratory Infections.

$\begin{array}{rlll}\text { Alivio-tos } & \begin{array}{l}\text { Alivio- } \\ \text { dolor de } \\ \text { garganta }\end{array} & \begin{array}{l}\text { Alivio- } \\ \text { ción } \\ \text { nasal }\end{array} & \begin{array}{l}\text { Control otros Total } \\ \text { fiebre }\end{array}\end{array}$

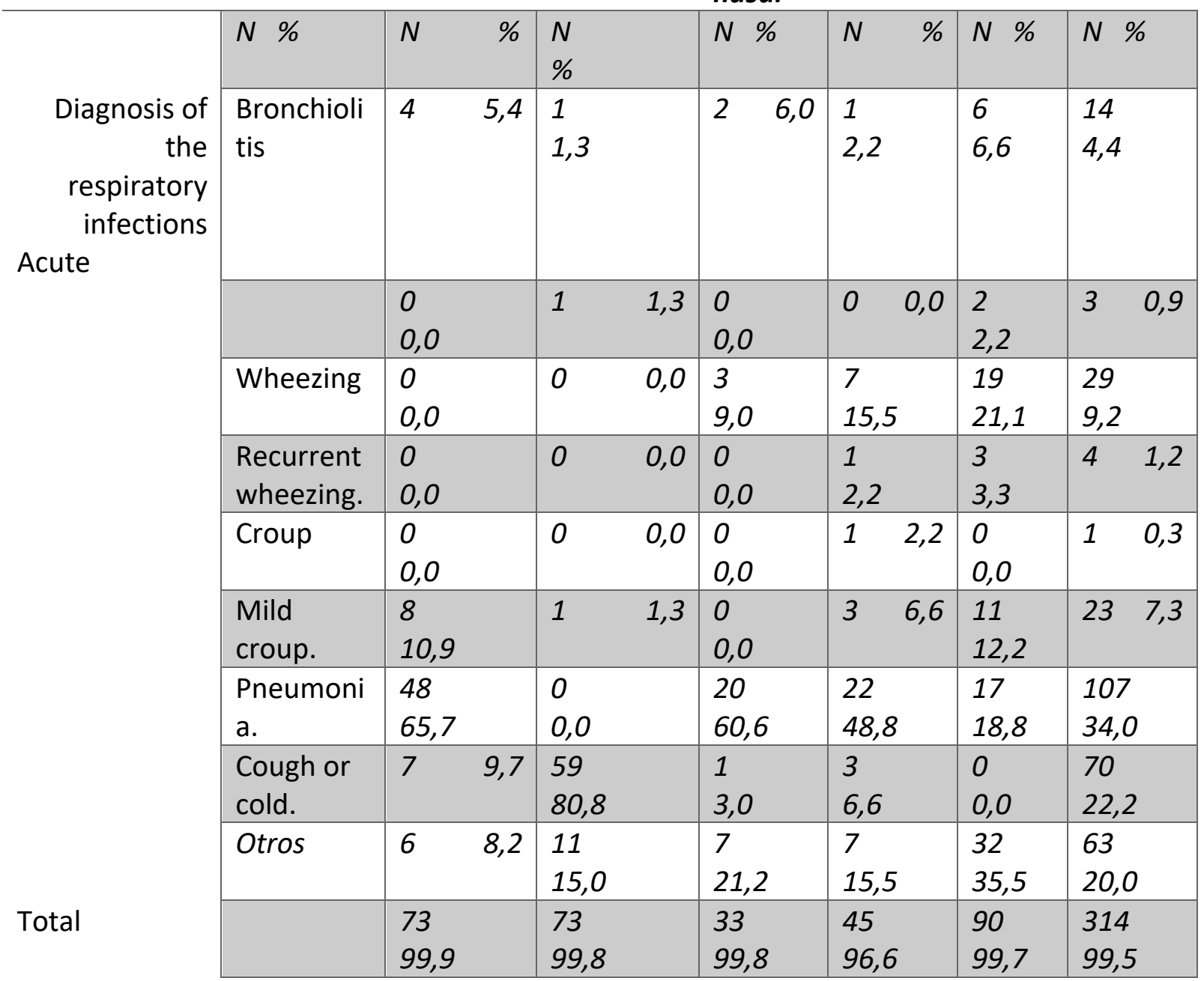

It is observed that simple counseling which is a treatment described in the IMCl strategy, there is prevalence of cough relief in cold and sore throat in pharyngo-tonsillitis with $65.7 \%$ and $80.8 \%$ respectively, followed by nasal obstruction relief with $60.6 \%$ and fever control with $48.8 \%$ mainly in cough or cold. 


\section{DISCUSIÓN}

It is important to determine the therapeutic management of children diagnosed with acute respiratory infections, and among these the use of antibiotics within the $\mathrm{IMCl}$ strategy. In this study, the Déleg Health Centre prescribed the largest amount of antibiotics as amoxicillin with 67.2\%. At the Javier Loyola Health Centre, $30.9 \%$ of the children were diagnosed with upper respiratory tract infections such as: coughing or common cold and pharyngo-tonsillitis. It is not specified whether it is viral or bacterial and they were prescribed antibiotics, there was a small percentage of pneumonia which $8.1 \%$, justifies the use of antibiotics. It should be mentioned that the classification and treatment described in IMCI for respiratory conditions is not applied, which increases the likelihood of increasing microbial resistance. The study entitled Implementation of the Integrated Management of Childhood Illnesses strategy in Ecuador indicates that antibiotics were also prescribed significantly more often when they were not indicated in the rural care centre, where $6.50 \%$ of excessive and unnecessary antibiotic use was recorded, meaning that patients only had a minor respiratory infection (9).

Non-streptococcal pharyngitis does not require antibiotic treatment, especially if the etiology is suspected to be viral. However, in cases of specific aetiology, amoxicillin-clavulanic acid, cephalosporins, clindamycin or macrolides may be used (main alternative in case of allergy to penicillins and derivatives (10).

In relation to what was cited in the study Comprehensive care of children with acute respiratory infection: the appropriateness and current use of clinical guidelines and decrease the abuse of antimicrobials and symptoms. The AIEPI strategy states that in the vast majority of cases of ARIs are of viral etiology in which there is still no useful antibiotic. Antibiotics are self-limiting in less than four days, in that the general condition improves and the fever decreases or disappears, since signs such as coughing or rhinorrhea can last up to 14 days. An exception is vesicular pharyngitis, in which pain and fever can last up to seven days. In these diseases, antibiotics should not be prescribed initially, but there is much to do: indicate and explain the general measures indicated in the guide, decrease the fever and general malaise with an antipyretic-analgesic such as paracetamol (acetaminophen), and identify the factors of poor prognosis; educate the mother about the natural evolution of the disease, about coughing as a defence mechanism that should be facilitated by fluidizing the secretions with water, about the uselessness and toxicity of antibiotics, antitussives and antihistamines, and about the identification of the four warning signs, in order to bring the child back as soon as possible(11). An important result found was the indiscriminate use of a non-steroidal anti-inflammatory analgesic (NSAID) such as ibuprofen and a systemic anti-histamine such as loratadine which are not reported in the management of acute respiratory infections and should be analyzed to determine whether they should be used in children according to the classification made and the diagnosis. With regard to paracetamol, it was evident that $45.7 \%$ of children in San Miguel were treated with this NSAID. In Déleg $81.3 \%$ treatment was associated between paracetamol and loratadine, and $30 \%$ ibuprofen plus loratadine.

According to the Spanish Association of Pediatrics in the last update of 2016 indicates that antihistamines can be used in children from 2 to 12 years, it is not recommended in children under 2 years (12). The technical data sheets of the medicines authorized in Spain have been obtained from the Online Information Center for Medicines of the Spanish Agency for Medicines and Healthcare Products. Many of these data sheets indicate that the safety and 
efficacy of antihistamines have not been sufficiently tested in younger children (13). However, there are several children in the study who were treated with anti-histamines that should be analyzed before prescription as they can produce complications in the child.

Of the total number of consultations for acute respiratory infections, the diagnoses that prevail in the health centres studied are: cough or cold $34 \%$, followed by pharyngoamyglalitis with $22.2 \%$, AIPI recommends simple counselling for the relief of minor symptoms. In case of fever and nasal obstruction, paracetamol is indicated; the use of antibiotics or antihistamines is not necessary. The study on Quality of Care for Children from 2 months to 4 years of age with the $\mathrm{IMCl}$ strategy carried out at the Iberia Health Center in the city of Cuenca found that $34.6 \%$ of the children presented cough/difficulty in breathing (14).

The study carried out by Ozaeta (15) in 2014 found that there was inadequate use of antibiotics in children who presented common colds; $80-90 \%$ of acute respiratory infections were viral. It has been demonstrated that early treatment with antibiotics, besides being ineffective, does not prevent complications, increases treatment costs, and many times is harmful because it favors the appearance of the phenomenon of bacterial resistance.

Acute respiratory infections by virus in children and adolescents studied in the municipality of Palma Soriano confirm that the probability of getting sick by ARI is higher the younger the child is, there being a greater vulnerability of natural barriers that prevent the development of the immune system. This risk increases primarily if the affected child is born preterm, since prematurity produces immunodeficiency due to poor maternal transfer of immunoglobulin $G$ and poor response in antibody formation. Early life is influenced not only by elements related to airway anatomy and the degree of lung parenchymal formation, but also by the immaturity of physiological defence mechanisms, all of which make children more susceptible to certain infectious and non-infectious entities (16).

Aguirre and Col. (17) in the study Morbidity due to acute respiratory infections in children under 5 years of age, the results obtained indicate a greater affectation in children under 1 year 55.3 , which coincides with the present study $28.6 \%$. Because at this age the natural barriers are more vulnerable due to the immaturity of the skin, lungs and intestines, the male sex predominated $58.1 \%$, a fact that coincides with what was obtained in the present study by $56.7 \%$, which is associated with the fact that the male sex presents a greater susceptibility to acquire respiratory infections, without there being an objective response to this problem.

\section{CONCLUSION}

A special thanks to the directors of the operating units of San Miguel, Javier Loyola and Déleg, as well as the students of the fifth cycle of the Nursing career at the Catholic University of Cuenca, Azogues headquarters.

\section{REFERENCIAS}

1. Lamos F, Durñan R, Docal maría, Soto L, SR. Construcción de un Modelo de Gestión para la Salud y Bienestar de la infancia en la Estrategía AIEPI en Colombia. Rev, Gerenc. Polit. Salud Bogota (Colombia). 2007; 6(12):126-143.

2. Martínez P , Cordero J , Valverde C UN, Dalmazzo R, Piemonte P, Vergara I, et al. Coinfección viral respiratoria en niños hospitalizados por infección respiratoria aguda y su impacto en la gravedad clínica. Rev. chil. infectol. 2012; 29(2): p. 169-174. 
3. Quizhpe A, E U, L E, D A, F B. Aplicación de la estrategia de Atención Integral de Enfermedades Prevalentes de la Infancia en Ecuador. Revista Cubana de Salud Pública. 2013; 39(2): p. 197- 207.

4. Guiscafré $H$, Ticomán $D$, Deleg $G, A$ M. La atención integral del niño con infección respiratoria aguda: lo apropiado y lo actual. Bol. Med. Hosp. Infant. 2008;65:p. 249-260.

5. Bernal C, Carvajal H, N. A. Costos económicos de la infección respiratoria aguda en un Municipio de Colombia. Rev Univ Ind Santander Salud. 2017: p. 470-477.

6. Pulgarín Á, Osorio S, Restrepo Y , A S. Conocimientos y prácticas del cuidador como factor asociado a enfermedad respiratoria aguda en niños de 2 meses a 5 años. Investigación y Educación en Enfermería. 2111; 29(1): p. 19-27.

7. Machado K, Notajeno M, Mello M, Pírez C, Giachetto G, w P. Infecciones respiratorias agudas bajas en niños menores de 2 años. Hospitalizaciones durante el invierno del año 2014. Scielo. 2018; 5(1).p.82-103.

8. Carmona D , Jaramillo E, Moreno A, Gil A , F L. Prácticas clave y conocimientos maternos de la Estrategia Aiepi en el Ambiente Comunitario. Rev. Fac. Nac. Salud Pública. 2017; 35(3): p. 432-443.

9. Martínez P , Cordero J , Valverde C UN, Dalmazzo R, Piemonte P, Vergara I, et al. Coinfección viral respiratoria en niños hospitalizados por infección respiratoria aguda y su impacto en la gravedad clínica. Rev. chil. infectol. 2012; 29(2): p. 169-174.

10.Aragón S. Tratamiento de las Infecciones Respiratorias Altas.Madrid.Elsevir.2010;29(6):p. 92-97.

11. H , Ticomán D, Deleg G , A M. La atención integral del niño con infección respiratoria aguda: lo apropiado y lo actual. Bol. Med. Hosp. Infant. 2008;: p. 249-260.

12.Calvo C, Núñez E, Piñeiro R, Escrig R, Manzano R, Cabrera L, Rodríguez Belen.Comité de Medicamentos de la Asociación Española de Pediatría. Pediamécum. Edición 2015.

13. Moral L, Toral T. Farmacoterapia de las enfermedades alérgicas. Protoc diagn ter pediatr. 2013; 1:107-19

14. Cando L.Escandon M. Calidad de atención del niño/a de 2 meses a 4 años de edad con la estrategia AIEPI. Revista de la Facultad de Ciencias Médicas de la Universidad de cuenca.

2015; 33(1): p. 1-50.

15.Ozaeta R. Caracterizacion en los niños menores de 5 años con catarro común. Pol. Con.2017;2(4):p. 224-234.

16. Goide E , Begué N, Martín M , Anaya Y , Y. N. Infecciones respiratorias agudas por virus en niños y adolescentes del. MEDISAN 2014; 18(9).

17. Aguirre E, Céspedes E, Rubal A, Maza A, Terán C. Morbilidad por infecciones respiratorias agudas en menores de 5 años. MEDISAN 2014;18(11):1490. 